\title{
The effects of pneumatic tube system transport on ROTEM analysis and contact activation assessed by thrombin generation test
}

Citation for published version (APA):

Lance, M. D., Kuiper, G. J. A. J. M., Sloep, M., Spronk, H. M. H., van Oerle, R., ten Cate, H., Marcus, M. A. E., \& Henskens, Y. M. C. (2012). The effects of pneumatic tube system transport on ROTEM analysis and contact activation assessed by thrombin generation test. Thrombosis Research, 130(3), E147-E150. https://doi.org/10.1016/j.thromres.2012.05.002

Document status and date:

Published: 01/09/2012

DOI:

10.1016/j.thromres.2012.05.002

Document Version:

Publisher's PDF, also known as Version of record

Document license:

Taverne

Please check the document version of this publication:

- A submitted manuscript is the version of the article upon submission and before peer-review. There can be important differences between the submitted version and the official published version of record.

People interested in the research are advised to contact the author for the final version of the publication, or visit the DOI to the publisher's website.

- The final author version and the galley proof are versions of the publication after peer review.

- The final published version features the final layout of the paper including the volume, issue and page numbers.

Link to publication

\footnotetext{
General rights rights.

- You may freely distribute the URL identifying the publication in the public portal. please follow below link for the End User Agreement:

www.umlib.nl/taverne-license

Take down policy

If you believe that this document breaches copyright please contact us at:

repository@maastrichtuniversity.nl

providing details and we will investigate your claim.
}

Copyright and moral rights for the publications made accessible in the public portal are retained by the authors and/or other copyright owners and it is a condition of accessing publications that users recognise and abide by the legal requirements associated with these

- Users may download and print one copy of any publication from the public portal for the purpose of private study or research.

- You may not further distribute the material or use it for any profit-making activity or commercial gain

If the publication is distributed under the terms of Article $25 \mathrm{fa}$ of the Dutch Copyright Act, indicated by the "Taverne" license above, 
Regular Article

\title{
The effects of pneumatic tube system transport on ROTEM analysis and contact activation assessed by thrombin generation test ${ }^{\text {th }}$
}

\author{
Marcus D. Lancé ${ }^{\mathrm{a}, *}$, Gerhardus J.A.J.M. Kuiper ${ }^{\mathrm{a}, \mathrm{b}}$, Matthijs Sloep ${ }^{\mathrm{a}}$, Henri M.H. Spronk ${ }^{\mathrm{b}}$, René van Oerle ${ }^{\mathrm{b}}$, \\ Hugo ten Cate ${ }^{b}$, Marco A.E. Marcus ${ }^{a}$, Yvonne M.C. Henskens ${ }^{c}$ \\ a Department of Anaesthesiology and Pain Treatment, Maastricht University Medical Centre +, Maastricht, the Netherlands \\ ${ }^{\mathrm{b}}$ Laboratory for Clinical Thrombosis and Haemostasis, Department of Internal Medicine, Maastricht University Medical Centre,+ Maastricht, the Netherlands \\ c Central Diagnostic Laboratory, Maastricht University Medical Centre + , Maastricht, the Netherlands
}

\section{A R T I C L E I N F O}

\section{Article history:}

Received 24 February 2012

Received in revised form 30 April 2012

Accepted 2 May 2012

Available online 25 May 2012

\section{Keywords:}

Pneumatic tube system

Point-of-care monitoring

ROTEM

Thromboelastometry

Contact activation

\begin{abstract}
A B S T R A C T
Thromboelastometry (ROTEM) is a popular point-of-care test. It generates results quickly and may benefit individualised guided haemostatic therapy. However, processing of specimens by non-technicians might decrease the quality and reproducibility of results. Centralised laboratory equipment receiving specimens through a pneumatic tube system (PTS) could avoid this. This study aimed to evaluate the influence of PTS transport on ROTEM results and its contribution to contact activation assessed by thrombin generation (TG). Methods: Specimens from 44 patients were drawn immediately after arterial puncture. Two were anticoagulated by citrate and two by citrate/corn trypsin inhibitor, a Factor XIla pathway inhibitor. Both types of samples were transported by walking and PTS. Subsequently, analysis was performed: ROTEM on citrated blood, and TG on citrated and corn trypsin inhibitor (CTI) blood using either 0 or 1 pM tissue factor (TF). Results: In ROTEM analysis the NATEM assay showed significant differences. The EXTEM assay revealed small significant differences for clot formation time: 65 seconds $(S D \pm 20$ ) versus 67 seconds (SD \pm 17 ), and alpha angle $79^{\circ}(S D \pm 3)$ versus $77^{\circ}(S D \pm 3)$. The results remained within reference range. TG was not significantly affected by the type of tube transport, independent of the amount of TF.

Conclusion: PTS for ROTEM analysis is feasible except for NATEM assays. The amount of contact activation via Factor XIIa in terms of TG is independent of transport type. However, due to the different characteristics of pneumatic systems, hospitals should check its impact on the results before introducing this route of transport.
\end{abstract}

Crown Copyright (c) 2012 Published by Elsevier Ltd. All rights reserved.

\section{Introduction}

Point-of-care (POC) laboratory monitoring is increasingly used in modern anaesthesiology. The main advantage of POC monitoring is rapid data acquisition, which enables treating patients in a more individualised way. Because anaesthesia teams who are tending to bleeding patients are occupied with stabilising vital functions, additional laboratory work (POC tests) might interfere with their regular workflow. In addition, there is concern about the quality and reproducibility of laboratory tests done by non-technicians, especially when the results are critically important in decision-making [1]. An alternative to the use of $\mathrm{POC}$ monitoring in the operating theatre

Abbreviations: POC, Point of care; PTS, pneumatic tube system; CTI, corn trypsin inhibitor; TG, thrombin generation; CAT, calibrated automated thrombogram; TF, tissue factor; LI, lysis index; CFT, clot formation time; VI, velocity index; TEG, thromboelstograph.

Presented as a poster on the ISTH 25-28.07.2011, Kyoto, Japan.

* Corresponding author at: Maastricht University Medical Centre+, Department of Anaesthesiology and Pain Treatment, P. Debyelaan 25, PO Box 5800, 6202 AZ Maastricht, The Netherlands. Tel.: + 3143 3877455; fax: + 31433875457 .

E-mail address: marcus.lance@mumc.nl (M.D. Lancé). might be to send specimens to the laboratory with minimal time delay. Pneumatic tube systems (PTS) reduce the workload and turnaround time of laboratories by accelerating the transport of blood samples, thus reducing manpower. While most haematological indices and standard coagulation indices are not influenced by transport via PTS [2-4], there have been reports of haemolysis in serum samples and in red blood cell concentrates, due to the acceleration and deceleration of PTS and due to vibration of the sample [5-7]. Haemolysis of red blood cells or platelets could lead to the generation of microparticles, which have been shown to trigger thrombin generation in a factor XII-dependent manner [13]. Most authors interpret these changes as minor and without clinical consequences. However, the transport by PTS of specific specimens such as for blood gas analysis, cerebral spinal fluid analysis, or platelet function analysis using the PFA-100® system is not recommended because results are unreliable [8-12].

On the other hand, Braun et al. showed that multiple electrode aggregrometry is possible by PTS transport of citrated samples of whole blood [14]. The influence of PTS transport on thromboelastometry (ROTEM-Tem International GmbH, Munich, Germany) has not been 
investigated with the type of PTS installed in our hospital and with the blood collection tubes we use (BD Vacutainer ${ }^{\circledR}$ tubes, Plymouth, UK). One of the drawbacks of PTS might be contact activation which can occur during and after collecting whole blood in test tubes [15]. Contact activation (via Factor XII) can be investigated by using citrated sample tubes with or without the addition of a Factor XII pathway inhibitor: corn trypsin inhibitor (CTI).

The aim of this study was to evaluate the influence of PTS transport on ROTEM results and to determine the contribution of contact activation caused by PTS. The latter was investigated using a thrombin generation (TG) assay and CTI as an activation inhibitor.

\section{Methods}

After approval by the local ethics board, 44 patients scheduled for elective cardiothoracic surgery at the Maastricht University Medical Centre gave written informed consent and were included in the study. Exclusion criteria were use of anticoagulants other than acetylsalicylic acid, and age younger than 18 years.

Upon arrival in the operating theatre, patients received standard monitoring for cardiac anaesthesia, including five lead electrocardiography, noninvasive blood pressure measurement and pulse oxymetry, a venous line (Vasofix ${ }^{\circledR}$ Safety, 16G or 14G, B. Braun Melsungen, Germany), which was inserted in the forearm, and an arterial line (Radial Artery Catheterization set, 20G, Arrow International, Reading, Pennsylvania, USA), which was positioned in the radial artery under subcutaneous local anaesthesia using $1 \mathrm{ml}$ of lidocaine $1 \%$ solution.

Blood was drawn out of the arterial line immediately after insertion. The first $10 \mathrm{~mL}$ were discarded before filling one ethylenediaminetetraacetic acid tube $\left(\mathrm{K}_{2}\right.$-EDTA $7.2 \mathrm{mg}$, BD Vacutainer ${ }^{\circledR}$ tubes, Plymouth, UK), two tubes containing citrate (sodium citrate 1.005 M, BD Vacutainer ${ }^{\circledR}$ tubes, Plymouth, UK) and two tubes with citrate and corn trypsin inhibitor (CTI $40 \mu \mathrm{g} / \mathrm{mL}$, Haematologic Technologies, Inc, Vermont, USA), a Factor XIIa inhibitor. Two sets of labelled tubes - both sets containing one citrate and one CTI tube - were sent to the central laboratory: one by PTS and one by walking transport. Platelet poor plasma (PPP) was prepared according to the standard protocol at our laboratory, consisting of an initial centrifugation step at $2.000 \times \mathrm{g}$ for 5 minutes ( $\mathrm{min}$ ) and a second centrifugation step at $10.000 \times \mathrm{g}$ for $10 \mathrm{~min}$. All aliquots were snap frozen in liquid nitrogen and stored at $-80^{\circ} \mathrm{C}$ until analysis.

The PTS (Swisslog-ErgoTrans BV, Apeldoorn, the Netherlands) connects the central surgical complex on the third floor with the haematological laboratory on the fifth floor. This circuit includes two switching stations for change of direction. There are no heat or cold sources along this route. The system generates a maximum speed of $8 \mathrm{~m} / \mathrm{s}$. Transport time from the operating theatres to the laboratory is between 83 and 110 seconds.

Sample analysis for the haematological parameters, haemoglobin, haematocrit and platelet count, was performed on a Beckman Coulter ${ }^{\circledR}$ LH-750 analyser (Beckman Coulter, Woerden, the Netherlands). ROTEM analysis was performed using the following standard assays according to the manufacturer's recommendations at $37^{\circ} \mathrm{C}$ : NATEM (recalcification, no trigger), INTEM (partial thromboplastin and ellagic acid), EXTEM (tissue factor) and FIBTEM (tissue factor and cytochalasin D) [16]. To investigate contact activation via Factor XIIa pathway as a possible cause of differences induced by PTS the remaining blood was centrifuged and TG was assessed using the Calibrated Automated Thrombogram ${ }^{\circledR}$ (CAT, Thrombinoscope BV, Maastricht, the Netherlands) with phospholipids ( $4 \mu \mathrm{M})$ using either 0 or $1 \mathrm{pM}$ tissue factor (TF). Previously, our group showed that normalization, with normal pooled plasma as a reference, of the time-independent parameters ETP and peak height is necessary to obtain acceptable inter-assay variations [17].
Considering 20\% difference from reference values (ROTEM) as clinically relevant 44 samples are necessary to reach a statistical power of $90 \%$ with an $\alpha$-error of 0.05 . Statistical analyses were performed using GraphPad Prism software (GraphPad Software, San Diego, California, USA). After testing for distribution the paired Student's $t$-test analysis for normally distributed variables and the Wilcoxon signed-rank test for nonparametric variables were used to compute the differences where applicable. A p-value of $<0.05$ was considered statistically significant.

\section{Results}

A total of 44 patients were included in this study. Thirty patients (68.2\%) were male and 14 (31.8\%) were female. The mean age was 69.7 years $(S D \pm 11.5)$. Haematological parameters revealed a mean haemoglobin of $7.7 \mathrm{mmol} / \mathrm{L}(\mathrm{SD} \pm 0.8$ ), a mean haematocrit of $0.38 \%$ $(\mathrm{SD} \pm 0.04)$, and a mean platelet count of $210 \times 10^{9} / \mathrm{L}\left(\mathrm{SD} \pm 60.1 \times 10^{9} / \mathrm{L}\right)$.

ROTEM analysis was done on all pairs of 44 citrated samples (transported by walking or with PTS) using the four ROTEM assays per run. The NATEM assay showed statistically significant differences $(p<0.05)$ for the transport method. Only the lysis index at 60 minutes (LI60) did not differ significantly. In the EXTEM assay, the clot formation time (CFT) 65 seconds ( $S D \pm 20$ ) versus 67 seconds ( $S \pm 17$ ), and the alpha angle $79^{\circ}(\mathrm{SD} \pm 3)$ versus $77^{\circ}(\mathrm{SD} \pm 3)$ revealed small significant differences (Table 1 ). However, all results were still within their specific reference range.

CAT analysis was performed on the blood samples of 31 of the 44 patients (citrate transported by walking or with PTS, and citrate/CTI transported by walking or with PTS). Blood from thirteen patients could not be sampled for CAT analysis because CTI tubes were not available.

Independent of the transport method, there is a significant inhibition of contact activation in all CTI tubes compared to citrate tubes. This difference is more pronounced when CAT analysis is triggered without tissue factor. There is no endogenous thrombin potential (ETP) without tissue factor triggering, and also no velocity index (VI) detectable in the CTI tubes. Whereas nearly an equal amount of contact activation is detectable within the group of citrate tubes (Table 2).

After triggering with $1 \mathrm{pM}$ tissue factor, the contact activation still was suppressed in the CTI tubes independent of transport method. Again the citrate tubes show an equal amount of contact activation in both groups (Walking versus PTS, Table 3).

\section{Discussion}

The present study demonstrates that PTS transport does not inflict clinically relevant consequences on ROTEM analysis results. Even though collection of blood samples is associated with a measurable degree of contact activation, in the CAT assay, this is not further enhanced by PTS transport as compared to manual (walking) transport to the laboratory.

Management of acute haemorrhage demands swift reaction and clinical decision-making. Some current literature recommends transfusing haemorrhagic patients as quickly as possible, even without knowledge of haemostatic properties, in order to prevent haemodilution and aggravation of bleeding [18]. Other authors state that ROTEM analysis provides important information on coagulation parameters in acute bleeding patients [19-21]. An actual debate at this moment is whether to perform ROTEM analysis at the bedside (i.e. operating theatre or emergency department) or at a central laboratory. The main argument supporting bedside testing is fast availability of results for tailored haemotherapy. On the other hand, concerns arise on the quality of POC results and some authors recommend performing laboratory analysis by trained technicians in the hospitals central laboratory [22-25]. 
Table 1

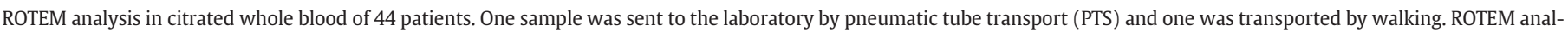

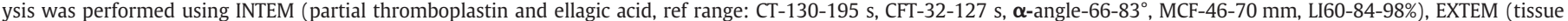

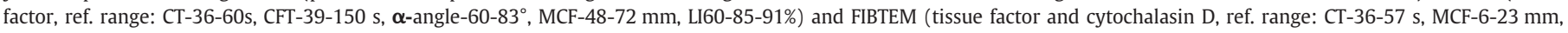

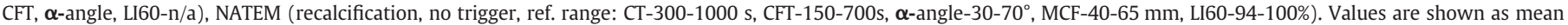
and min-max values. CT: clotting time, CFT: clot formation time, MCF: mean clot firmness, LI60: lysis index *significant pneumatic system vs. walking, n/a not applicable.

\begin{tabular}{|c|c|c|c|c|c|c|c|c|c|c|c|c|}
\hline & \multicolumn{3}{|l|}{ INTEM } & \multicolumn{3}{|l|}{ EXTEM } & \multicolumn{3}{|l|}{ FIBTEM } & \multicolumn{3}{|l|}{ NATEM } \\
\hline & PTS & Walking & P-value & PTS & Walking & P-value & PTS & Walking & P-value & PTS & Walking & P-value \\
\hline $\mathrm{CT}(\mathrm{s})$ & $135(97-172)$ & 137 (83-189) & 0.47 & 35 (24-49) & $35(18-57)$ & 0.93 & $33(10-53)$ & $33(22-57)$ & 0.73 & $508(213-846)$ & $571(187-990)$ & $0.01^{*}$ \\
\hline CFT(s) & $64(36-103)$ & 63 (40-99) & 0.54 & 65 (36-119) & 67 (33-107) & $0.02 *$ & $\mathrm{n} / \mathrm{a}$ & $\mathrm{n} / \mathrm{a}$ & $\mathrm{n} / \mathrm{a}$ & $127(46-263)$ & $136(54-305)$ & $0.03^{*}$ \\
\hline Alpha angle $\left({ }^{\circ}\right)$ & $78(73-83)$ & $78(71-82)$ & 0.17 & $79(68-84)$ & $77(68-84)$ & $0.01^{*}$ & $\mathrm{n} / \mathrm{a}$ & $\mathrm{n} / \mathrm{a}$ & $\mathrm{n} / \mathrm{a}$ & $67(47-80)$ & 65 (44-79) & $0.04^{*}$ \\
\hline $\mathrm{MCF}(\mathrm{mm})$ & $62(51-76)$ & $62(52-75)$ & 0.56 & $63(51-77)$ & $62(53-77)$ & 0.08 & $18(10-25)$ & $18(9-26)$ & 0.57 & $61(51-72)$ & $60(46-79)$ & $0.01^{*}$ \\
\hline LI60 (\%) & 91 (86-97) & 91 (86-97) & 0.50 & $90(79-98)$ & 91 (84-97) & 0.16 & $\mathrm{n} / \mathrm{a}$ & $\mathrm{n} / \mathrm{a}$ & $\mathrm{n} / \mathrm{a}$ & $93(85-98)$ & $92(86-97)$ & 0.82 \\
\hline
\end{tabular}

The main argument against determination of ROTEM in a central laboratory is the time consuming walking transport of blood samples. PTS transport may reduce this transportation time. However, rapid transport in pneumatic systems may influence reliability of results by platelet activation and/or contact activation. Several authors reported significant effects on laboratory parameters when transport by PTS was used $[6,8,12]$. For this reason PTS transport was not recommended for several POC tests $[10,12]$. Wallin and colleagues described significant differences in $r$ time on the thromboelastograph (TEG) when they compared walking transport with PTS [26]. Unfortunately, the authors do not describe which trigger substances (kaoline/tissue factor) were used. This might be of interest because tissue factor activation reveals significantly different results comparing citrated with native fresh blood samples [27]. However these results are in accordance with our findings, because the NATEM assay reveals also a shortening of the CT which reflects the initiation of clot forming as the r-time in the TEG does. Assuming that Wallin and co-workers used the most common trigger substance (kaolin) one might interpret this activation not as strong as the activation by ellagic acid which is the activator in the INTEM assay. The stronger activation in this assay might explain why we do not see a prolongation of the CT here. This might be also an explanation for the EXTEM and FIBTEM assays where the activator might be stronger. At the same time, all results of Wallin were within reference ranges and would also not impact treatment strategy [28]. Another recent study revealed no significant differences in ROTEM analysis when PTS transport was performed. However, these results cannot be automatically generalised to other hospitals since tube transport has different features in terms of switching points, speed and acceleration/ deceleration [24]. Furthermore, we used different collection tubes, namely BD tubes instead of Sarsted tubes. Generally, there are two differences between these collecting systems. First, our system is a glass tube system which may activate the Factor XIIa pathway of coagulation [29]. Due to this, the amount of contact activation may differ significantly between ours and the plastic system of Sarsted, which Colucci and colleagues used. Further, the Sarsted system does not collect blood by vacuum suction, but with a plunger. This may lead to inconsistent filling

Table 2

Calibrated Automated Thrombogram (CAT) analysis in citrated whole blood with or without Corn Trypsin Inhibitor (CTI) of 31 patients. One citrate and citrate/CTI sample was sent to the laboratory by pneumatic tube transport (PTS) and one was transported by walking. CAT was performed with phospholipids $(4 \mu \mathrm{M})$ triggered by 0 pM tissue factor (TF). Values are shown as medians (Q1-Q3). No significant differences were seen (Wilcoxon signed-rank test: $\mathrm{p}>0.05$ ). LT: lag time, PH: peak height, ETP: endogenous thrombin potential, VI: velocity index.

\begin{tabular}{lcclcc}
\hline & Citrate 0 pM TF & & \multicolumn{2}{l}{ Citrate and CTI 0 pM TF } \\
\cline { 2 - 3 } \cline { 5 - 6 } & PTS & Walking & & PTS & Walking \\
\hline LT $($ min $)$ & $12(10-15)$ & $13(10-17)$ & & $99(38-99)$ & $62(28-99)$ \\
PH $(\mathrm{nM})$ & $292(179-331)$ & $296(218-333)$ & & $1(0-1)$ & $1(0-1)$ \\
ETP $(\mathrm{nM} / \mathrm{min})$ & $1278(791-1450)$ & $1287(957-1386)$ & & $0(0-0)$ & $0(0-0)$ \\
VI $(\mathrm{nM} / \mathrm{min})$ & $137(78-172)$ & $144(91-167)$ & & $0(0-0)$ & $0(0-0)$ \\
\hline
\end{tabular}

of the tubes which may translate into different mixtures with the anticoagulants. Vacuum suction might induce stronger contact activation due to higher shear stress than a plunger system as suggested by Lippi and co-workers who compared different blood drawing techniques [30].

Another possible reason for the differences between PTS and walking transport might be an activation of platelets. However this might be of minor influence because platelet activity is poorly reflected in ROTEM analysis [31]. On the other hand is the amount of platelet activation in PTS still a matter of debate. As showed by our group and by others is platelet function not always altered by PTS [10,14,32].

In the present study, some statistically significant differences were seen with the NATEM parameters and the alpha angle of the EXTEM assay. Still, all the results were within normal range, as determined by Lang et al., and as such, would not affect patient management [33].

The thrombin generation assay is a powerful tool to reflect small changes in the coagulation system $[34,35]$. Therefore, it was used to investigate the potential effect of contact activation induced by PTS. The use of CTI, a specific Factor XIla inhibitor, eliminates the possible effect of contact activation. CAT analysis was performed in paired tubes (with or without CTI and/or PTS) in order to investigate whether the small differences in the ROTEM results might reflect contact activation via Factor XIla pathway due to transport. However, no influences of transport PTS could be detected, and it seems there is no additive stimulation of this pathway.

From clinical practice, it is known that an acutely bleeding patient requires intense manpower support on the scene, limiting the time available to perform additional tests by team members themselves. In addition, working under pressure might result in less reliable laboratory results [36], and might lead to a large variability and lack of reproducibility $[25,37]$. In the UK, Kitchen et al. demonstrated a precision in ROTEM results that vary between 7 and 84 per cent in POC settings in hospitals [25]. Moreover, to maintain a high assay quality, a quality control programme needs to be established and performed by dedicated people [37-39]. Because of this, it remains preferable to maintain carrying out POC tests in the laboratory.

Table 3

Calibrated Automated Thrombogram (CAT) analysis in citrated whole blood with or without Corn Trypsin Inhibitor (CTI) of 31 patients. One citrate and citrate/CTI sample was sent to the laboratory by pneumatic tube transport (PTS) and one was transported by walking. CAT was performed with phospholipids $(4 \mu \mathrm{M})$ triggered by $1 \mathrm{pM}$ tissue factor (TF). The results are normalised with standard plasma for the sake of interpretation. Values are shown as medians (Q1-Q3). No significant differences were seen (Wilcoxon signed-rank test: $\mathrm{p}>0.05$ ). LT: lag time, nPH: normalised peak height, nETP: normalised endogenous thrombin potential, VI: velocity index.

\begin{tabular}{lcclcc}
\hline & \multicolumn{2}{c}{ Citrate 1 pM TF } & & \multicolumn{2}{c}{ Citrate and CTI 1 pM TF } \\
\cline { 2 - 3 } \cline { 5 - 6 } & PTS & Walking & & PTS & Walking \\
\hline LT (min) & $3(3-4)$ & $3(3-4)$ & & $4(4-5)$ & $4(4-5)$ \\
nPH (\% of normal) & $183(116-206)$ & $183(134-208)$ & & $74(53-103)$ & $74(55-111)$ \\
nETP (\% of normal) & $120(89-134)$ & $118(95-134)$ & & $82(72-101)$ & $84(74-101)$ \\
VI (nM/min) & $86(60-120)$ & $88(56-121)$ & & $21(14-34)$ & $20(14-36)$ \\
\hline
\end{tabular}


In conclusion, our study demonstrated the feasibility of PTS transport for ROTEM analysis. The amount of contact activation via the Factor XIla pathway in terms of thrombin generation is independent of transport method. Because of the differences between the PTS - in terms of distance length of time and maximum speed - and the type of collection tubes used, each hospital should check the impact of transport in its own system before implementation this route of transport.

\section{Conflict of Interest Statement}

None of the authors has a conflict of interest.

\section{Funding}

This investigation was done without external funding.

\section{References}

[1] Chitlur M, Lusher J. Standardization of thromboelastography: values and challenges. Semin Thromb Hemost 2010;36:707-11.

[2] Guss DA, Chan TC, Killeen JP. The impact of a pneumatic tube and computerized physician order management on laboratory turnaround time. Ann Emerg Med 2008;51:181-5.

[3] Fernandes CM, Worster A, Eva K, Hill S, McCallum C. Pneumatic tube delivery system for blood samples reduces turnaround times without affecting sample quality. J Emerg Nurs 2006;32:139-43.

[4] Keshgegian AA, Bull GE. Evaluation of a soft-handling computerized pneumatic tube specimen delivery system. Effects on analytical results and turnaround time. Am J Clin Pathol 1992;97:535-40.

[5] Ando H, Nieminen K, Toppila E, Starck J, Ishitake T. Effect of impulse vibration on red blood cells in vitro. Scand J Work Environ Health 2005;31:286-90.

[6] Sodi R, Darn SM, Stott A. Pneumatic tube system induced haemolysis: assessing sample type susceptibility to haemolysis. Ann Clin Biochem 2004;41:237-40.

[7] Stair TO, Howell JM, Fitzgerald DJ, Bailey SC, Bastasch MD. Hemolysis of blood specimens transported from ED to laboratory by pneumatic tube. Am J Emerg Med 1995; 13:484.

[8] Collinson PO, John CM, Gaze DC, Ferrigan LF, Cramp DG. Changes in blood gas samples produced by a pneumatic tube system. J Clin Pathol 2002;55:105-7.

[9] Wenham PR, Hanson T, Ashby JP. Interference in spectrophotometric analysis of cerebrospinal fluid by haemolysis induced by transport through a pneumatic tube system. Ann Clin Biochem 2001;38:371-5.

[10] Dyszkiewicz-Korpanty A, Quinton R, Yassine J, Sarode R. The effect of a pneumatic tube transport system on PFA-100 trade mark closure time and whole blood platelet aggregation. J Thromb Haemost 2004;2:354-6.

[11] Hubner U, Bockel-Frohnhofer N, Hummel B, Geisel J. The effect of a pneumatic tube transport system on platelet aggregation using optical aggregometry and the PFA-100. Clin Lab 2010;56:59-64.

[12] Bolliger D, Seeberger MD, Tanaka KA, Dell-Kuster S, Gregor M, Zenklusen U, et al. Pre-analytical effects of pneumatic tube transport on impedance platelet aggregometry. Platelets 2009;20:458-65.

[13] van der Meijden PE, van Schilfgaarde M, van Oerle R, Renne T, Ten Cate H, Spronk HM. Platelet- and erythrocyte-derived microparticles trigger thrombin generation via Factor XIla. J Thromb Haemost Apr. 26, 2012, doi:10.1111/j.1538-7836.2012.04758.x [Electronic publication ahead of print].

[14] Braun S, von Beckerath N, Ellert J, Kastrati A, Schomig A, Vogt W, et al. Assessment of platelet function in whole blood by multiple electrode aggregometry: transport of samples using a pneumatic tube system. Am J Clin Pathol 2009;132:802-3 [author reply 3-4].

[15] Spronk HM, Dielis AW, Panova-Noeva M, van Oerle R, Govers-Riemslag JW, Hamulyak K, et al. Monitoring thrombin generation: is addition of corn trypsin inhibitor needed? Thromb Haemost 2009;101:1156-62.

[16] Mittermayr M, Streif W, Haas T, Fries D, Velik-Salchner C, Klingler A, et al. Hemostatic changes after crystalloid or colloid fluid administration during major orthopedic surgery: the role of fibrinogen administration. Anesth Analg 2007;105:905-17 [table of contents].

[17] Spronk HM, Dielis AW, De Smedt E, van Oerle R, Fens D, Prins MH, et al. Assessment of thrombin generation II: Validation of the Calibrated Automated Thrombogram in platelet-poor plasma in a clinical laboratory. Thromb Haemost 2008;100:362-4

[18] Johansson PI, Stensballe J. Effect of Haemostatic Control Resuscitation on mortality in massively bleeding patients: a before and after study. Vox Sang 2009;96: 111-8.

[19] Frith D, Brohi K. The acute coagulopathy of trauma shock: clinical relevance. Surgeon 2010;8:159-63.

[20] Johansson PI, Stensballe J. Hemostatic resuscitation for massive bleeding: the paradigm of plasma and platelets-a review of the current literature. Transfusion 2010;50:701-10.

[21] Rugeri L, Levrat A, David JS, Delecroix E, Floccard B, Gros A, et al. Diagnosis of early coagulation abnormalities in trauma patients by rotation thrombelastography. J Thromb Haemost 2007;5:289-95.

[22] du Plessis M, Ubbink JB, Vermaak WJ. Analytical quality of near-patient blood cholesterol and glucose determinations. Clin Chem 2000;46:1085-90.

[23] Briedigkeit L, Muller-Plathe O, Schlebusch H, Ziems J. Recommendations of the German Working Group on medical laboratory testing (AML) on the introduction and quality assurance of procedures for Point-of-Care Testing (POCT) in hospitals. Clin Chem Lab Med 1999;37:919-25.

[24] Colucci G, Giabbani E, Barizzi G, Urwyler N, Alberio L. Laboratory-based ROTEM((R)) analysis: implementing pneumatic tube transport and real-time graphic transmission. Int J Lab Hematol 2011;33:441-6.

[25] Kitchen DP, Kitchen S, Jennings I, Woods T, Walker I. Quality assurance and quality control of thrombelastography and rotational Thromboelastometry: the UK NEQAS for blood coagulation experience. Semin Thromb Hemost 2010;36:757-63.

[26] Wallin O, Soderberg J, Grankvist K, Jonsson PA, Hultdin J. Preanalytical effects of pneumatic tube transport on routine haematology, coagulation parameters, platelet function and global coagulation. Clin Chem Lab Med 2008;46:1443-9.

[27] Wasowicz M, Srinivas C, Meineri M, Banks B, McCluskey SA, Karkouti K. Technical report: analysis of citrated blood with thromboelastography: comparison with fresh blood samples. Can J Anaesth 2008;55:284-9.

[28] Scarpelini S, Rhind SG, Nascimento B, Tien H, Shek PN, Peng HT, et al. Norma range values for thromboelastography in healthy adult volunteers. Braz J Med Biol Res 2009;42:1210-7.

[29] Bowen RA, Hortin GL, Csako G, Otanez OH, Remaley AT. Impact of blood collection devices on clinical chemistry assays. Clin Biochem 2010;43:4-25.

[30] Lippi G, Salvagno GL, Brocco G, Guidi GC. Preanalytical variability in laboratory testing: influence of the blood drawing technique. Clin Chem Lab Med 2005;43: 319-25.

[31] Gorlinger K, Jambor C, Dirkmann D, Dusse F, Hanke A, Adamzik M, et al. Platelet function analysis with point-of-care methods. Herz 2008;33:297-305.

[32] Lance MD, Marcus MA, van Oerle R, Theunissen HM, Henskens YM. Platelet concentrate transport in pneumatic tube systems - does it work? Vox Sang Jan. 5, 2012, doi:10.1111/j.1423-0410.2011.01580.x [Electronic publication ahead of print].

[33] Lang T, Bauters A, Braun SL, Potzsch B, von Pape KW, Kolde HJ, et al. Multi-centre investigation on reference ranges for ROTEM thromboelastometry. Blood Coagul Fibrinolysis 2005;16:301-10.

[34] Hemker HC, Al Dieri R, De Smedt E, Beguin S. Thrombin generation, a function test of the haemostatic-thrombotic system. Thromb Haemost 2006;96:553-61.

[35] Ten Cate H. Thrombin generation in clinical conditions. Thromb Res 2012;129: 367-70.

[36] Croskerry P, Abbass A, Wu AW. Emotional influences in patient safety. J Patient Saf 2010;6:199-205.

[37] Mauch J, Spielmann N, Hartnack S, Madjdpour C, Kutter AP, Bettschart-Wolfensberger $\mathrm{R}$, et al. Intrarater and interrater variability of point of care coagulation testing using the ROTEM delta. Blood Coagul Fibrinolysis 2011;22:662-6.

[38] Dick A, Schwaiger M, Jambor C. Thromboelastography/-metry and external quality control. Results of a pilot study. Hamostaseologie 2010;30:91-5.

[39] Chitlur M, Sorensen B, Rivard GE, Young G, Ingerslev J, Othman M, et al. Standardization of thromboelastography: a report from the TEG-ROTEM working group. Haemophilia 2011;17:532-7. 